\title{
Structural Characterization of the GM1 \\ Ganglioside by Infrared Multiphoton \\ Dissociation, Electron Capture Dissociation, and Electron Detachment Dissociation Electrospray Ionization FT-ICR MS/MS
}

\author{
Melinda A. McFarland, ${ }^{+}$Alan G. Marshall, ${ }^{+}$ \\ Christopher L. Hendrickson, ${ }^{+}$and Carol L. Nilsson ${ }^{*}$ \\ Ion Cyclotron Resonance Program, National High Magnetic Field Laboratory, Florida State University, \\ Tallahassee, Florida, USA
}

\author{
Pam Fredman ${ }^{\ddagger}$ and Jan-Eric Månsson ${ }^{\ddagger}$ \\ Institute of Clinical Neuroscience, Sahlgrenska University Hospital, Göteborg University, Mölndal, Sweden
}

Gangliosides play important biological roles and structural characterization of both the carbohydrate and the lipid moieties is important. The FT-ICR MS/MS techniques of electron capture dissociation (ECD), electron detachment dissociation (EDD), and infrared multiphoton dissociation (IRMPD) provide extensive fragmentation of the protonated and deprotonated GM1 ganglioside. ECD provides extensive structural information, including identification of both halves of the ceramide and cleavage of the acetyl moiety of the $\mathrm{N}$-acetylated sugars. IRMPD provides similar glycan fragmentation but no cleavage of the acetyl moiety. Cleavage between the fatty acid and the long-chain base of the ceramide moiety is seen in negative-ion IRMPD but not in positive-ion IRMPD of GM1. Furthermore, this extent of fragmentation requires a range of laser powers, whereas all information is available from a single ECD experiment. However, stepwise fragmentation by IRMPD may be used to map the relative labilities for a series of cleavages. EDD provides the alternative of electron-induced fragmentation for negative ions with extensive fragmentation, but suffers from low efficiency as well as complication of data analysis by frequent loss of hydrogen atoms. We also show that analysis of MS/MS data for glycolipids is greatly simplified by classification of product ion masses to specific regions of the ganglioside based solely on mass defect graphical analysis. (J Am Soc Mass Spectrom 2005, 16, 752-762) (c) 2005 American Society for Mass Spectrometry

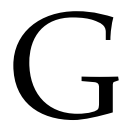
angliosides are amphiphilic components localized mainly in the outer leaf of cell membranes. The structure of a ganglioside includes a ceramide tail (fatty acid N-linked to a sphingosine) of varying length, saturation, and hydroxylation linked to a polar carbohydrate head that contains sialic (neuraminic) acid (Figure 1). The complexity of the carbohydrate moiety makes for complex nomenclature; the current convention has been developed by Svennerholm [1]. The gangliosides are grouped according to

Published online March 16, 2005

Address reprint requests to Dr. C. L. Nilsson, Ion Cyclotron Resonance Program, National High Magnetic Field Laboratory, Florida State University, 1800 E. Paul Dirac Dr., Tallahassee, FL 32310-4005, USA. E-mail: nilsson@magnet.fsu.edu

* Also at the Institute of Medical Biochemistry, Göteborg University, Box 440, SE-40530 Göteborg, Sweden.

† Also a member of the Department of Chemistry and Biochemistry, Florida State University, Tallahassee, FL, USA.

$\ddagger$ Institute of Clinical Neuroscience, Göteborg University, Mölndal, Sweden. the number of their sialic acid residues: one (M), two (D), or three (T). The G1 series contains a tetraose chain $(\mathrm{Gal} \beta 1 \rightarrow$ 3GalNAc $\beta 1 \rightarrow 4 \mathrm{Gal} \beta 1 \rightarrow 4 \mathrm{Glc})$, whereas G2 glycolipids lack the terminal galactose and G3 lack the terminal disaccharide $(\mathrm{Gal} \beta 1 \rightarrow$ 3GalNAc). Therefore, the GM1 ganglioside (Figure 1) denotes a glycolipid that contains a monosialylated tetraose oligosaccharide $(\mathrm{Gal} \beta 1 \rightarrow 3 \mathrm{GalNAc} \beta 1 \rightarrow$ $4(\mathrm{NeuAc} \alpha 2 \rightarrow 3) \mathrm{Gal} \beta 1 \rightarrow 4 \mathrm{Glc} \beta 1 \rightarrow 1^{\prime} \mathrm{Cer}$ ).

The biological roles of gangliosides include cell-cell recognition, contact inhibition, cell adhesion, and tissue differentiation [2-4]. Although they are found in all tissues, they are particularly enriched in the central nervous system [5]. The carbohydrate portion of the molecule is directed toward the exterior of the cell and mediates molecular recognition. The ceramide composition is cell-specific [6] and provides a hydrophobic anchor. Ceramide modulates glycolipid function [3, 7-9], perhaps by changing the orientation of the carbo- 


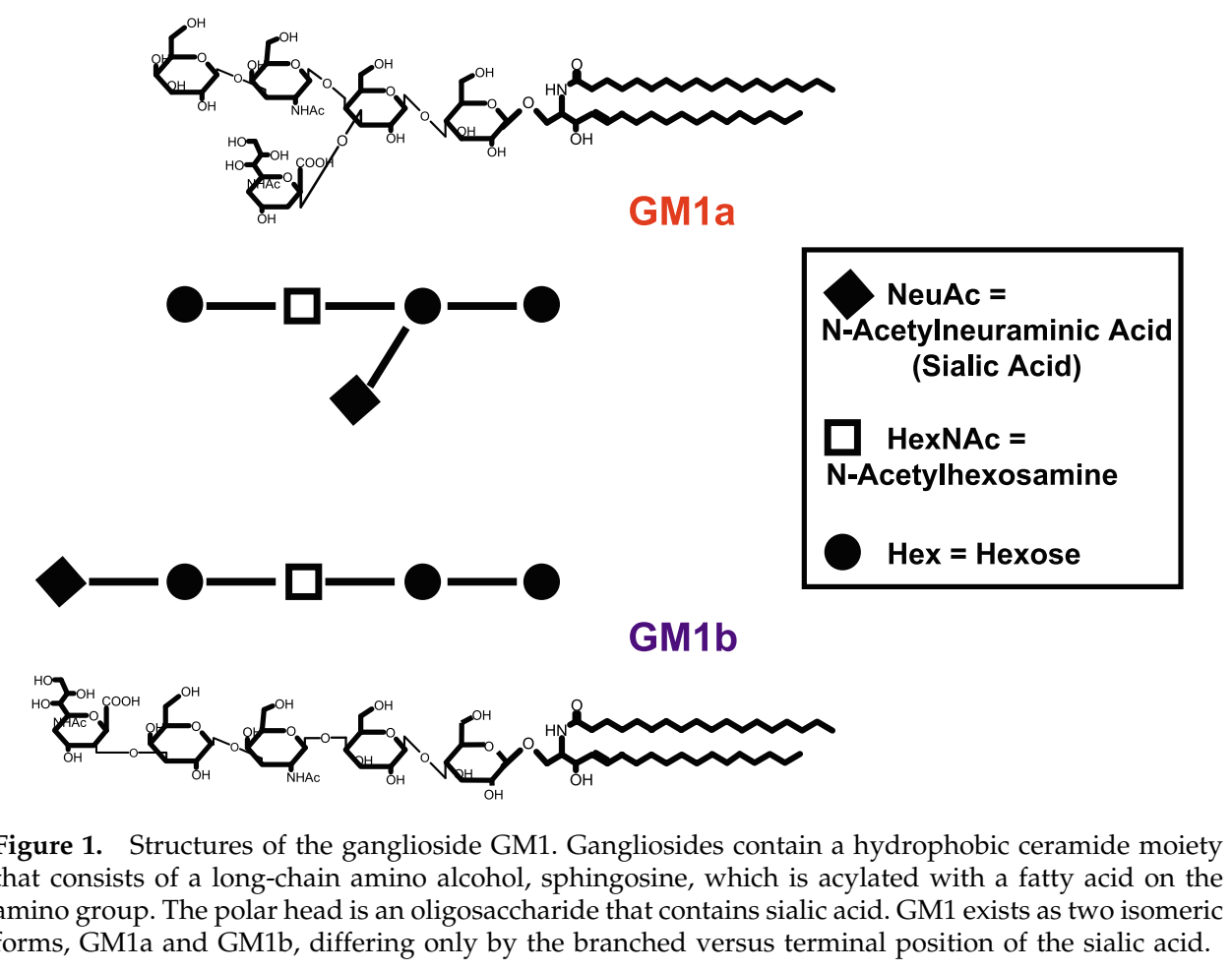

hydrate relative to the cell surface. Therefore, structural studies of glycolipids should include characterization of both the lipid and the carbohydrate moieties.

Mass spectrometry has been employed extensively to study glycolipid structures. Fast atom bombardment ionization (FAB)-MS [10,11] and FAB-MS/MS studies [12] of glycolipids successfully determined the structures of both the lipid and the carbohydrate portions of those molecules. However, FAB is a relatively harsh and insensitive ionization technique, which can cause extensive precursor ion fragmentation that complicates mixture analysis. More gentle ionization modes such as matrix-assisted laser desorption/ionization (MALDI) and electrospray ionization (ESI) have also been successful in the analysis of glycolipids. Juhasz and Costello studied underivatized and permethylated gangliosides containing one to five sialic acid residues and different lipid residues by positive- and negative-ion MALDI-TOF MS [13]. ESI has been employed in the analysis of gangliosides with different ceramides isolated from white blood cells [14], gangliosides from complex mixtures obtained from human granulocytes [15], and to obtain profiles of lipids extracted from human brain [16, 17].

Fourier transform ion cyclotron resonance (FT-ICR) mass spectrometry $[18,19]$ offers high resolving power and high mass accuracy. Dissociation techniques applied to FT-ICR MS analysis of biomolecules include sustained off-resonance collisionally-activated dissociation [20-22] (SORI-CAD), infrared multiphoton dissociation [23, 24] (IRMPD), electron capture dissociation $[25,26](E C D)$, and electron detachment dissociation [27] (EDD). SORI-CAD has been employed to charac- terize lipooligosaccharides from the pathogen Haemophilus influenzae [28] and galactosylceramide from pig intestine [29]. ECD has been used to localize sites of O-glycosylation [30] and fatty acid posttranslational modifications in peptides [31]. Recently, Budnik et al. combined ECD and CAD in order to characterize chitooligosaccharides from natural and synthetic sources [32]. We have previously characterized $\mathrm{N}$-linked glycopeptides by ECD and IRMPD, demonstrating the complementarity of structural information obtained from each dissociation technique [33]. Here, we demonstrate the utility of ECD, EDD and IRMPD for the structural characterization of the ganglioside, GM1.

The slow heating IRMPD technique provides a variable duration of irradiation which can be employed to control the extent of secondary fragmentation, thereby accessing fragmentation pathways not available by single-pass CAD external to the ICR cell. The in-cell dissociation techniques of IRMPD, ECD, and EDD eliminate the loss of dynamic range, crucial to detection of single sugars, associated with transfer of externally generated product ions into the ICR cell and do so without the pumpdown delay necessary for in-cell SORI-CAD. For gangliosides, IRMPD produces extensive fragmentation of both positive and negative ions. The "nonergodic" ECD technique provides a more random and more extensive distribution of fragmentation sites. Consequently, ECD produces extensive primary fragmentation with short duration (milliseconds) electron irradiation and a better picture of connectivity between sugars. EDD provides an electron irradiation alternative for negative ions but more complex fragmentation patterns. 


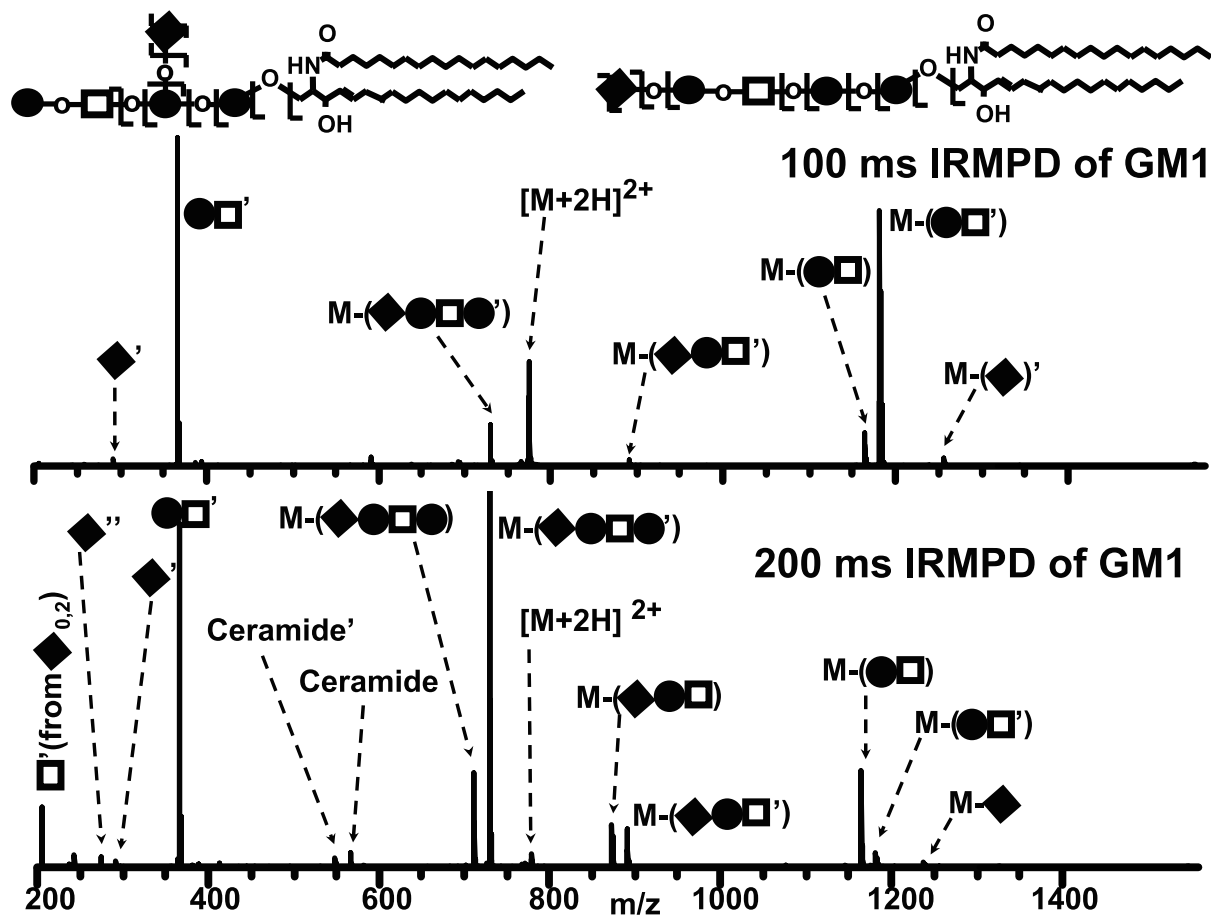

Figure 2. (Top) Product positive-ion spectrum following IRMPD (100 ms, $8 \mathrm{~W})$ FT-ICR MS/MS of the quadrupole isolated doubly protonated GM1 precursor (30 scans). This spectrum suggests that the dominant fragment, HexHexNAc' at $m / z 366.139$, is most likely the initial site of fragmentation of GM1a. All fragment ions are singly charged. (Filled diamond, NeuAc $=\mathrm{N}$-acetylneuraminic acid or sialic acid; filled circle, Hex=hexose; open square, HexNAc $=\mathrm{N}$-acetyl hexosamine). (The prime symbol denotes loss of $\mathrm{H}_{2} \mathrm{O}$ ). (Symbol with a through bar denotes cross-ring cleavage). (Bottom) Product positive-ion mass spectrum under the same conditions as Figure 3a, except that the duration of IRMPD irradiation has been lengthened to $200 \mathrm{~ms}$ (30 scans). Anomeric cleavage is seen, except at the nonreducing end of HexNAc. Much of the additional fragmentation at longer irradiation most likely arises from secondary fragmentation of the M-HexHexNAc' product ion, which makes the presence of the GM1b isomer ambiguous.

\section{Methods}

\section{Sample Preparation}

GM1-ganglioside from bovine brain was isolated and characterized at the Institute of Clinical Neuroscience $[34,35]$. The GM1 sample contained no detectable amount of the lactotetraose series gangliosides 3'-LM1 and 3 '-iso-LM1 [36]. Thin layer chromatography followed by chemical detection with resorcinol showed only the occurrence of GM1a. Due to the detection limit of the resorcinol reagent, the occurrence of GM1b can't be excluded but is $<0.2 \%$. Dehydrated samples were resuspended to a concentration of $100 \mu \mathrm{M}$ in methanol (Baker, Philipsburg, NJ). For electrospray, samples were diluted to a concentration of 3 to $5 \mu \mathrm{M}$ in 1:1 water/ methanol with $3 \%$ acetic acid for positive ionization or $100 \%$ methanol for negative ionization.

\section{Fourier Transform Ion Cyclotron Resonance Mass Spectrometry}

All experiments were performed with a homebuilt $9.4 \mathrm{~T}$ passively shielded ESI-Q-FT-ICR mass spectrometer [37] controlled by a modular ICR data acquisition system (MIDAS) [38]. Samples were infused at a flow rate of $350 \mathrm{~nL} / \mathrm{min}$ through a $50 \mu \mathrm{m}$ i.d. fused silica capillary with a mechanically ground tip [39]. For external ion accumulation [40,41], ions are held in a focusing octopole followed by precursor ion mass selection in a quadrupole mass filter and subsequent accumulation in a linear octopole ion trap $(30 \mathrm{~s}$ for positive ions and $5 \mathrm{~s}$ for negative ions). Negative ions are further isolated in the ICR cell by stored waveform inverse Fourier transform (SWIFT) isolation [42, 43]. The accumulation octopole has been modified for improved ion extraction to include tilted wires that produce an axial potential gradient [44]. Prior to dissociation, ions are transferred through an octopole ion guide to an open-ended cylindrical Penning trap [45].

The instrument configuration for simultaneous access to both electron and photon irradiation has been previously described [46]. For IRMPD, an off-axis $(\sim 2.5$ degrees) $\mathrm{CO}_{2}$ laser (Synrad, Mukilteo, WA) fitted with a $2.5 \times$ beam expander irradiates the ion cloud through a $\mathrm{BaF}_{2}$ window. For ECD and EDD, a $1 \mathrm{~cm}$ diameter dispenser cathode electron source (no. 1109; HeatWave, Watsonville, CA) is positioned on-axis approximately 73 $\mathrm{cm}$ behind the ICR cell. Normally the molybdenum grid 
Table 1. Molecular assignments and neural masses of product ions of GM1 in IRMPD of the doubly protonated precursor ion

\begin{tabular}{|c|c|c|c|c|c|c|}
\hline (z) & Measured $\mathrm{m} / \mathrm{z}$ & $\Delta$ Precursor & Assignment & Formula & $\begin{array}{c}\text { Calculated } \\
\mathrm{m} / \mathrm{z}\end{array}$ & Error (ppm) \\
\hline (1) & 204.0864 & 1342.7976 & HexNAc' or $A 1$ of $\mathrm{Neu}^{\prime} c^{\prime}$ & $\mathrm{C}_{8} \mathrm{H}_{13} \mathrm{NO}_{5}$ & 204.0867 & +1.2 \\
\hline (1) & 274.0919 & 1272.7921 & NeuAc" & $\mathrm{C}_{11} \mathrm{H}_{15} \mathrm{NO}_{7}$ & 274.0921 & +0.5 \\
\hline (1) & 292.1024 & 1254.7816 & NeuAc' & $\mathrm{C}_{11} \mathrm{H}_{17} \mathrm{NO}_{8}$ & 292.1027 & +0.9 \\
\hline (1) & 366.1392 & 1180.7448 & HexHexNAc' & $\mathrm{C}_{14} \mathrm{H}_{23} \mathrm{NO}_{10}$ & 366.1395 & +0.7 \\
\hline (1) & 530.5294 & 1016.3546 & ceramide" & $\mathrm{C}_{36} \mathrm{H}_{67} \mathrm{NO}$ & 530.5295 & +0.1 \\
\hline (1) & 548.5399 & 998.3441 & cermide' & $\mathrm{C}_{36} \mathrm{H}_{69} \mathrm{NO}_{2}$ & 548.5401 & +0.3 \\
\hline (1) & 566.5506 & 980.3334 & ceramide & $\mathrm{C}_{36} \mathrm{H}_{71} \mathrm{NO}_{3}$ & 566.5507 & +0.1 \\
\hline (1) & 710.5933 & 836.2907 & M-HexHexNAcHexNeuAc & $\mathrm{C}_{42} \mathrm{H}_{79} \mathrm{NO}_{7}$ & 710.5929 & -0.6 \\
\hline (1) & 728.6042 & 818.2798 & M-(HexHexNAcHexNeuAc)' & $\mathrm{C}_{42} \mathrm{H}_{81} \mathrm{NO}_{8}$ & 728.6035 & -1.0 \\
\hline (1) & 872.6475 & 674.2365 & M-HexHexNAcNeuAc & $\mathrm{C}_{48} \mathrm{H}_{89} \mathrm{NO}_{12}$ & 872.6457 & -2.1 \\
\hline (1) & 890.6572 & 656.2268 & M-(HexHexNAcNeuAc) $)^{\prime}$ & $\mathrm{C}_{48} \mathrm{H}_{91} \mathrm{NO}_{13}$ & 890.6563 & -1.1 \\
\hline (1) & 1163.7429 & 383.1411 & $\mathrm{M}-\mathrm{HexHexNAc}$ & $\mathrm{C}_{59} \mathrm{H}_{106} \mathrm{~N}_{2} \mathrm{O}_{20}$ & 1163.7412 & -1.5 \\
\hline (1) & 1181.7549 & 365.1291 & $\mathrm{M}-(\mathrm{HexHexNAc})^{\prime}$ & $\mathrm{C}_{59} \mathrm{H}_{108} \mathrm{~N}_{2} \mathrm{O}_{21}$ & 1181.7517 & -2.8 \\
\hline (1) & 1237.7798 & 309.1042 & $\mathrm{M}-\mathrm{NeuAc}$ & $\mathrm{C}_{62} \mathrm{H}_{112} \mathrm{~N}_{2} \mathrm{O}_{22}$ & 1237.7779 & -1.6 \\
\hline (1) & 1255.7867 & 291.0973 & M-NeuAc' & $\mathrm{C}_{62} \mathrm{H}_{114} \mathrm{~N}_{2} \mathrm{O}_{23}$ & 1255.7884 & +1.3 \\
\hline (1) & 1325.7984 & 221.0856 & M-A1 of NeuAc & $\mathrm{C}_{65} \mathrm{H}_{116} \mathrm{~N}_{2} \mathrm{O}_{25}$ & 1325.7939 & -3.4 \\
\hline (1) & 1528.8685 & 18.0155 & {$[\mathrm{M}+\mathrm{H}]^{+}-\mathrm{H}_{2} \mathrm{O}$} & $\mathrm{C}_{73} \mathrm{H}_{129} \mathrm{~N}_{3} \mathrm{O}_{30}$ & 1528.8731 & +3.0 \\
\hline (1) & 1546.8825 & 0.0015 & {$[\mathrm{M}+\mathrm{H}]^{+}$} & $\mathrm{C}_{73} \mathrm{H}_{131} \mathrm{~N}_{3} \mathrm{O}_{31}$ & 1546.8838 & +0.8 \\
\hline
\end{tabular}

( $80 \%$ transmission) is held at $-200 \mathrm{~V}$ to impede the flow of electrons. For ECD (of positive ions) the cathode voltage is biased to $-5 \mathrm{~V}$, the grid to $+5 \mathrm{~V}$, and the ICR cell trap plates to $+10 \mathrm{~V}$. Following ECD, a 1 ms event in which the trap plates are dropped to $+2 \mathrm{~V}$, grid to $+5 \mathrm{~V}$, and cathode to $+10 \mathrm{~V}$ is used to purge any remaining electrons from the ICR cell. For EDD (of negative ions) the cathode voltage is biased to $-8 \mathrm{~V}$, the grid to $+200 \mathrm{~V}$ and the trap plates to $-5 \mathrm{~V}$. Following dissociation ions undergo frequency-sweep excitation $(72$ to $960 \mathrm{kHz}$ at $150 \mathrm{~Hz} / \mu \mathrm{s}$, $m / z$ 150-2000) and broadband detection (512 Kword data points). The digitized time domain transient signal is

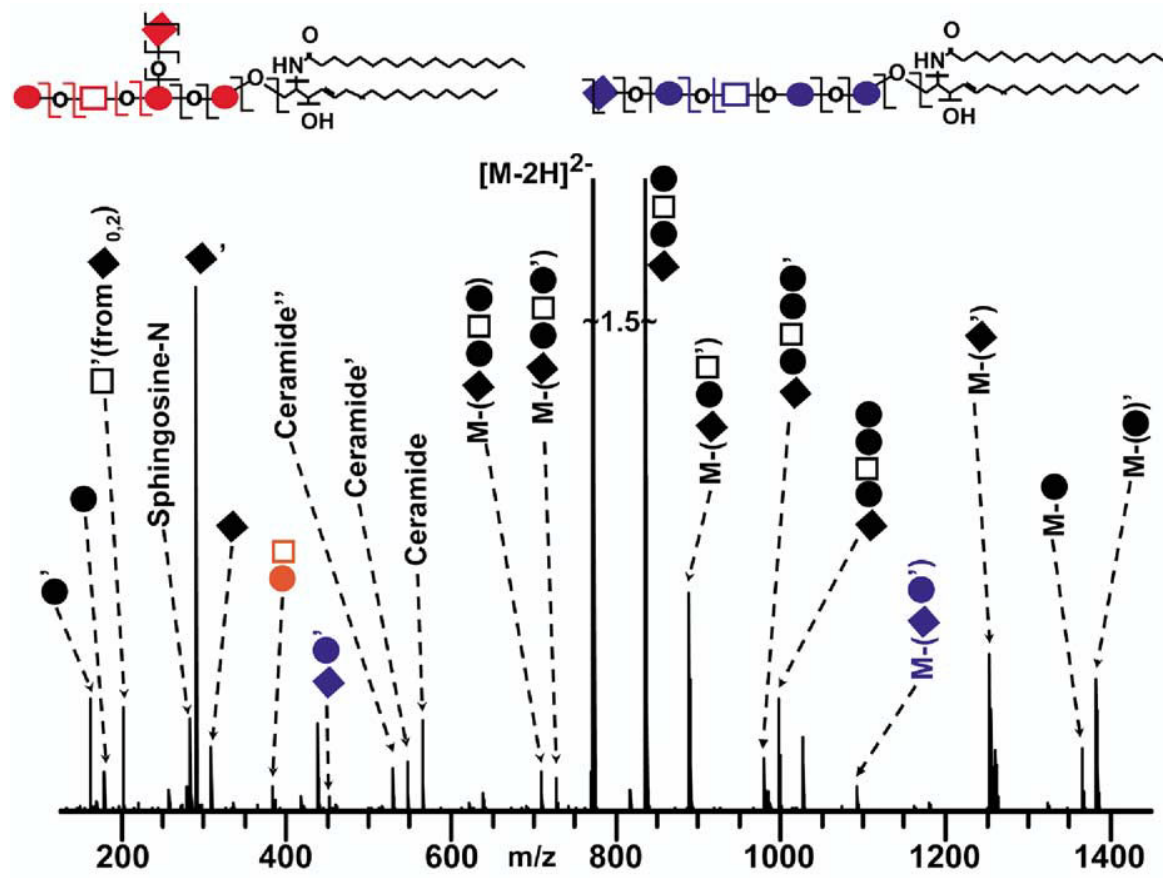

Figure 3. Product negative-ion mass spectrum following IRMPD (200 ms, $14 \mathrm{~W}$ ) of doubly deprotonated GM1 precursor (100 scans). Fragmentation is more extensive than for IRMPD of the doubly protonated form. In contrast to IRMPD of the protonated form, these fragments include cleavage within the ceramide moiety associated with loss of the fatty acid. Product ions that can belong only to GM1a are shown in red; those which suggest GM1b are shown in blue. Presence of a GM1b as a minor component is evident from the fragment ion peak at $m / z 1091.722$ which corresponds to a loss of the disaccharide HexNeuAc' from the precursor and its disaccharide complement at $m / z$ 452.141. (All fragment ions are singly charged.) 
Table 2. Molecular assignments and neutral masses of product ions of GM1 in IRMPD of the doubly deprotonated precursor ion

\begin{tabular}{|c|c|c|c|c|c|c|}
\hline (z) & Measured $\mathrm{m} / \mathrm{z}$ & $\Delta$ Precursor & Assignment & Formula & $\begin{array}{c}\text { Calculated } \\
\mathrm{m} / \mathrm{z}\end{array}$ & Error (ppm) \\
\hline (1) & 161.0453 & 1383.8240 & hexose' & $\mathrm{C}_{6} \mathrm{H}_{10} \mathrm{O}_{5}$ & 161.0456 & +1.6 \\
\hline (1) & 179.0558 & 1365.8135 & hexose & $\mathrm{C}_{6} \mathrm{H}_{12} \mathrm{O}_{6}$ & 179.0562 & +2.0 \\
\hline (1) & 202.0718 & 1342.7975 & HexNAc' or $\mathrm{A} 1$ of $\mathrm{Neu} A c^{\prime}$ & $\mathrm{C}_{8} \mathrm{H}_{13} \mathrm{NO}_{5}$ & 202.0722 & +1.7 \\
\hline (1) & 283.2638 & 1261.6055 & sphingosine- $\mathrm{N}$ & $\mathrm{C}_{18} \mathrm{H}_{36} \mathrm{O}_{2}$ & 283.2643 & +1.6 \\
\hline (1) & 290.0877 & 1254.7816 & NeuAc' & $\mathrm{C}_{11} \mathrm{H}_{17} \mathrm{NO}_{8}$ & 290.0882 & +1.6 \\
\hline (1) & 308.0983 & 1236.7710 & NeuAc & $\mathrm{C}_{11} \mathrm{H}_{19} \mathrm{NO}_{9}$ & 308.0988 & +1.5 \\
\hline (1) & 382.1348 & 1162.7345 & HexHexNAc & $\mathrm{C}_{14} \mathrm{H}_{25} \mathrm{NO}_{11}$ & 382.1356 & +2.0 \\
\hline (1) & 452.1405 & 1092.7288 & HexNeuAc' & $\mathrm{C}_{17} \mathrm{H}_{27} \mathrm{NO}_{13}$ & 452.1410 & +1.0 \\
\hline (1) & 528.5145 & 1016.3548 & ceramide" & $\mathrm{C}_{36} \mathrm{H}_{67} \mathrm{NO}$ & 528.5150 & +0.9 \\
\hline (1) & 546.5252 & 998.3441 & ceramide' & $\mathrm{C}_{36} \mathrm{H}_{69} \mathrm{NO}_{2}$ & 546.5257 & +0.8 \\
\hline (1) & 564.5356 & 980.3337 & ceramide & $\mathrm{C}_{36} \mathrm{H}_{71} \mathrm{NO}_{3}$ & 564.5362 & +1.0 \\
\hline (1) & 708.5784 & 836.2909 & M-HexHexNAcHexNeuAc & $\mathrm{C}_{42} \mathrm{H}_{79} \mathrm{NO}_{7}$ & 708.5784 & -0.1 \\
\hline (1) & 726.5889 & 818.2804 & M-HexHexNAcHexNeuAc' & $\mathrm{C}_{42} \mathrm{H}_{81} \mathrm{NO}_{8}$ & 726.5890 & +0.1 \\
\hline (2) & 771.9308 & 0.0004 & {$[\mathrm{M}-2 \mathrm{H}]^{2-}$} & $\mathrm{C}_{73} \mathrm{H}_{131} \mathrm{~N}_{3} \mathrm{O}_{31}$ & 771.9310 & +0.3 \\
\hline (1) & 817.2734 & 727.5959 & HexHexNAcHexNeuAc' & $\mathrm{C}_{31} \mathrm{H}_{50} \mathrm{~N}_{2} \mathrm{O}_{23}$ & 817.2731 & -0.4 \\
\hline (1) & 835.2841 & 709.5852 & HexHexNAcHexNeuAc & $\mathrm{C}_{31} \mathrm{H}_{52} \mathrm{~N}_{2} \mathrm{O}_{24}$ & 835.2837 & -0.5 \\
\hline (1) & 888.6421 & 656.2272 & M-(HexHexNAcNeuAc') & $\mathrm{C}_{48} \mathrm{H}_{91} \mathrm{NO}_{13}$ & 888.6418 & -0.4 \\
\hline (1) & 979.3257 & 565.5436 & glycan' & $\mathrm{C}_{37} \mathrm{H}_{60} \mathrm{~N}_{2} \mathrm{O}_{28}$ & 979.3259 & +0.2 \\
\hline (1) & 997.3375 & 547.5318 & glycan & $\mathrm{C}_{37} \mathrm{H}_{62} \mathrm{~N}_{2} \mathrm{O}_{29}$ & 997.3365 & -1.1 \\
\hline (1) & 1073.7081 & 471.1612 & M-(HexNeuAc) & $\mathrm{C}_{56} \mathrm{H}_{102} \mathrm{~N}_{2} \mathrm{O}_{17}$ & 1073.7106 & +2.3 \\
\hline (1) & 1091.7216 & 453.1477 & M-(HexNeuAc') & $\mathrm{C}_{56} \mathrm{H}_{104} \mathrm{~N}_{2} \mathrm{O}_{18}$ & 1091.7211 & -0.5 \\
\hline (1) & 1161.7301 & 383.1392 & $\mathrm{M}-(\mathrm{HexHexNAc)}$ & $\mathrm{C}_{59} \mathrm{H}_{106} \mathrm{~N}_{2} \mathrm{O}_{20}$ & 1161.7267 & -3.0 \\
\hline (1) & 1179.7367 & 365.1326 & $\mathrm{M}-\left(\mathrm{HexHexNAc^{ \prime } )}\right.$ & $\mathrm{C}_{59} \mathrm{H}_{108} \mathrm{~N}_{2} \mathrm{O}_{21}$ & 1179.7372 & +0.4 \\
\hline (1) & 1253.7756 & 291.0937 & M-NeuAc' & $\mathrm{C}_{62} \mathrm{H}_{114} \mathrm{~N}_{2} \mathrm{O}_{23}$ & 1253.7739 & -1.4 \\
\hline (1) & 1260.5987 & 284.2706 & $\mathrm{M}-($ fattyacid-H)-H2O & $\mathrm{C}_{55} \mathrm{H}_{95} \mathrm{~N}_{3} \mathrm{O}_{29}$ & 1260.5978 & -0.8 \\
\hline (1) & 1323.782 & 221.0873 & M-A1 of NeuAc & $\mathrm{C}_{65} \mathrm{H}_{116} \mathrm{~N}_{2} \mathrm{O}_{25}$ & 1323.7794 & -2.0 \\
\hline (1) & 1364.8076 & 180.0617 & M-Gal & $\mathrm{C}_{67} \mathrm{H}_{119} \mathrm{~N}_{3} \mathrm{O}_{25}$ & 1364.8059 & -1.3 \\
\hline (1) & 1382.8166 & 162.0527 & M-Gal' & $\mathrm{C}_{67} \mathrm{H}_{121} \mathrm{~N}_{3} \mathrm{O}_{26}$ & 1382.8165 & -0.1 \\
\hline
\end{tabular}

Hanning apodized and one zero-fill applied prior to fast Fourier transformation to yield a magnitude mode frequency spectrum that is converted to a mass-to charge ratio spectrum with a two-term calibration equation [47, 48]. All precursor ions are doubly protonated or doubly deprotonated. All product ions are singly protonated or singly deprotonated. All spectra are externally calibrated with Agilent ESI tuning mix ions $(\mathrm{m} / \mathrm{z}$ 622.02895, 922.00979, and 1521.97146, Agilent Technologies, Wilmington, DE). Molecular formulas were derived from calibrated masses with an in-house molecular formula calculator and theoretical masses were calculated with Isopro 3.1 (MS/MS software, http://members.aol.com/ msmssoft/). All MS and MS/MS assignments have a mass accuracy of $3 \mathrm{ppm}$ or better.

\section{Results and Discussion}

GM1 was analyzed as both positive and negative ions with a 9.4 T ESI-Q-FT-ICR mass spectrometer. GM1 exists as two major species in brain differing by ceramide chain lengths, d18:1/C18:0 and d20:1/C18:0 [49]. All present experiments derive from the quadrupoleisolated $\mathrm{d} 18: 1 / \mathrm{C} 18: 0$ form.

\section{Infrared Multiphoton Dissociation (IRMPD) of Positive Ions}

Figure 2 (top) shows the product ion spectrum obtained from IRMPD (100 ms, 8W) FT-ICR MS/MS of quadrupole-isolated doubly protonated GM1 d18:1/ C18:0 precursor ions (30 scans). IRMPD is a slow heating technique and therefore cleaves the weakest bonds first [50]. The irradiation period of $100 \mathrm{~ms}$ represents the initial threshold for fragmentation; loss of the disaccharide HexHexNAc' $\left({ }^{\prime}=-\mathrm{H}_{2} \mathrm{O}\right)$ thus identifies the initial cleavage site. No fragments corresponding to terminal NeuAcHex and NeuAcHexHexNac could be detected in this spectrum. This result confirms the GM1a isomer as the principal species. Because only the most labile bonds are broken, one learns only a little about the carbohydrate and nothing about the ceramide portion of the ganglioside.

Fortunately, the primary IRMPD fragment ions remain trapped in the path of the IR beam, and may thus continue to absorb IR power until secondary fragmentation (of stronger bonds) occurs. The extent of fragmentation may thus be adjusted by varying the duration of IR irradiation. Figure 2 (bottom) (Table 1) shows the FT-ICR MS/MS spectrum for a longer IR-irradiation period ( $200 \mathrm{~ms}, 8 \mathrm{~W})$ under otherwise identical conditions (30 scans). Much more extensive information results from further fragmentation of the

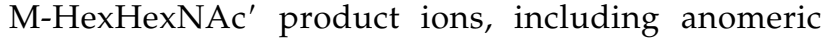
cleavage between adjacent sugars, except at the nonreducing end of HexNAc. Fragmentation of both positive and negative ions produces a neutral loss equal to the mass of HexNAc as well as the corre- 


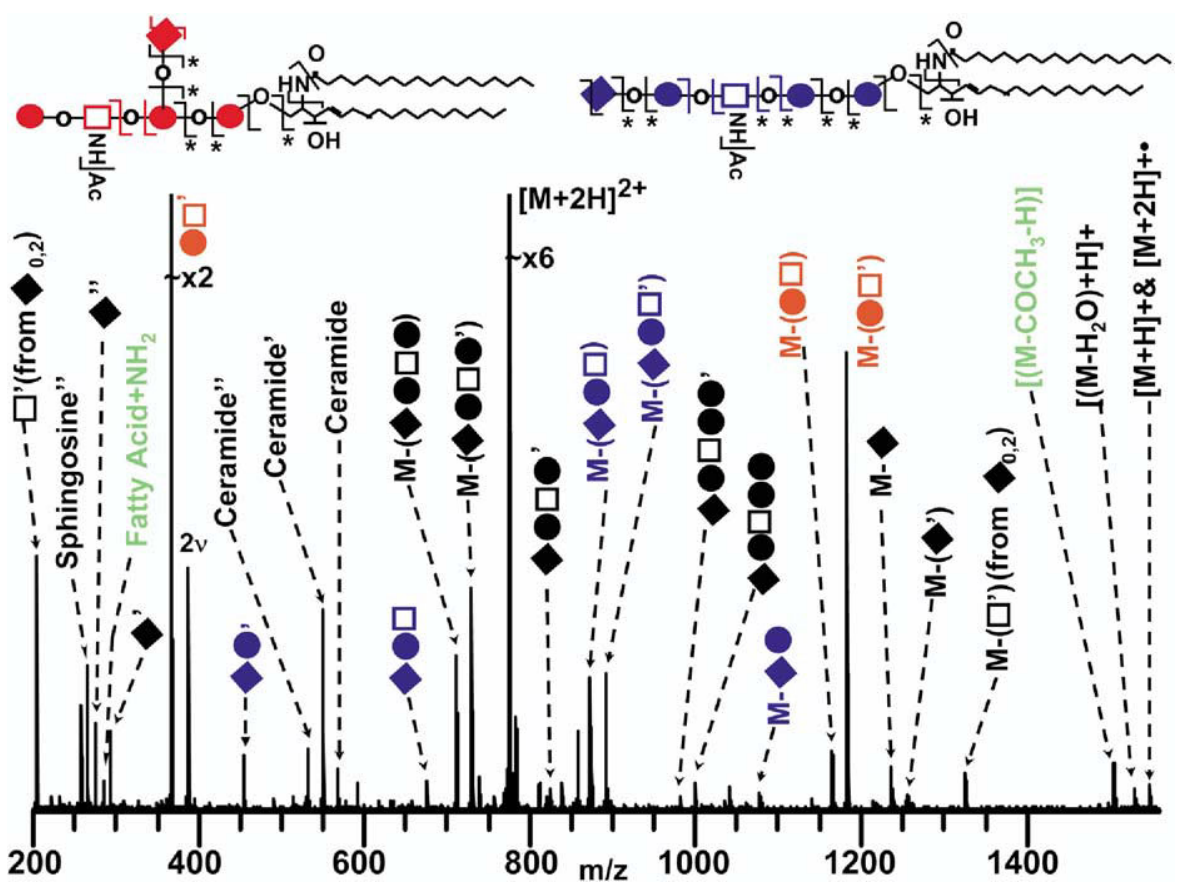

Figure 4. Product positive-ion mass spectrum following ECD (50 ms irradiation) of doubly protonated GM1 (50 scans). ECD gives the most extensive fragmentation of the present methods, yielding product ions identifying both the fatty acid and sphingosine chains of the ceramide region. ECD also provides complementary polysaccharide fragment ions for all M-sugar fragments. Product ion peaks labeled in green represent fragments seen only by ECD, including loss of the acetyl moiety, confirming the presence of N-acetylated sugars. All fragment ions are singly charged. Fragments labeled with stars indicate an additional peak corresponding to a loss of $2 \mathrm{H}$ associated with the loss of sialic acid.

sponding monosaccharide. Those products likely arise from cross-ring cleavage of sialic acid, corresponding to the loss of 221.1 Da and the retention of pyruvic acid. Particularly important for glycosphingolipids is the presence of diagnostic peaks at $\mathrm{m} / \mathrm{z} 566.551$ and 548.540 corresponding to the intact ceramide and ceramide minus $\mathrm{H}_{2} \mathrm{O}$ portion of the molecule.

\section{Infrared Multiphoton Dissociation (IRMPD) of Negative Ions}

The same GM1 sample was subjected to negative ionization. Figure 3 (Table 2) shows the IRMPD MS/MS spectrum of the doubly deprotonated d18:1/ C18:0 GM1 precursor (200 ms, $14 \mathrm{~W}, 100$ scans). The IRMPD negative-ion fragmentation of GM1 is more extensive than for positive ions and offers more detailed data for structural analysis of GM1, including cleavage at all glycosidic bonds. This is the only case in which we observe the fragment corresponding to the hexose single residue mass of $162.053 \mathrm{Da}$. Also helpful is the retention of multiple polysaccharides in the fragment ions, in particular the entire glycan. Fragments corresponding to the ceramide are more pronounced than for the protonated precursor and they appear as a diagnostic trio of peaks; ceramide as well as a single and double water loss. Secondary fragmentation of the ceramide separates the fatty acid from the long-chain base that appears as the sphingosine-N fragment (see also Figure 6). Fragmentation within the ceramide moiety was not seen for IRMPD of the doubly protonated GM1, although fragmentation within the ceramide was seen by positive-ion IRMPD of sulfatides with the same instrument (data not shown).

GM1 exists as two isomeric forms, GM1a and GM1b (also called cis-GM1 [1]), which differ only by the branched versus terminal position of the sialic acid (Figure 1). Although samples were thought to contain only GM1a, the spectra suggest that a small amount of the GM1b isomer is also present. Fragments that can derive only from GM1a are labeled in red, those from GM1b in blue, and those that could come from either in black. As in the positive-ion spectrum, Figure 3 shows a peak at $\mathrm{m} / \mathrm{z} 888.642$ corresponding to M-HexHexNAcNeuAc' and suggesting the presence of the GM1b isomer. However, as there is no corresponding trisaccharide peak observed in either spectrum, this fragment could be the result of secondary fragmentation. More conclusive to the presence of a less abundant GM1b component is the fragment ion peak at $m / z 1091.7216 \mathrm{Da}$ which corresponds to a loss of the disaccharide HexNeuAc' from the precursor and, importantly, its disaccharide complement at $m / z 452.141$ (Figure 3). 

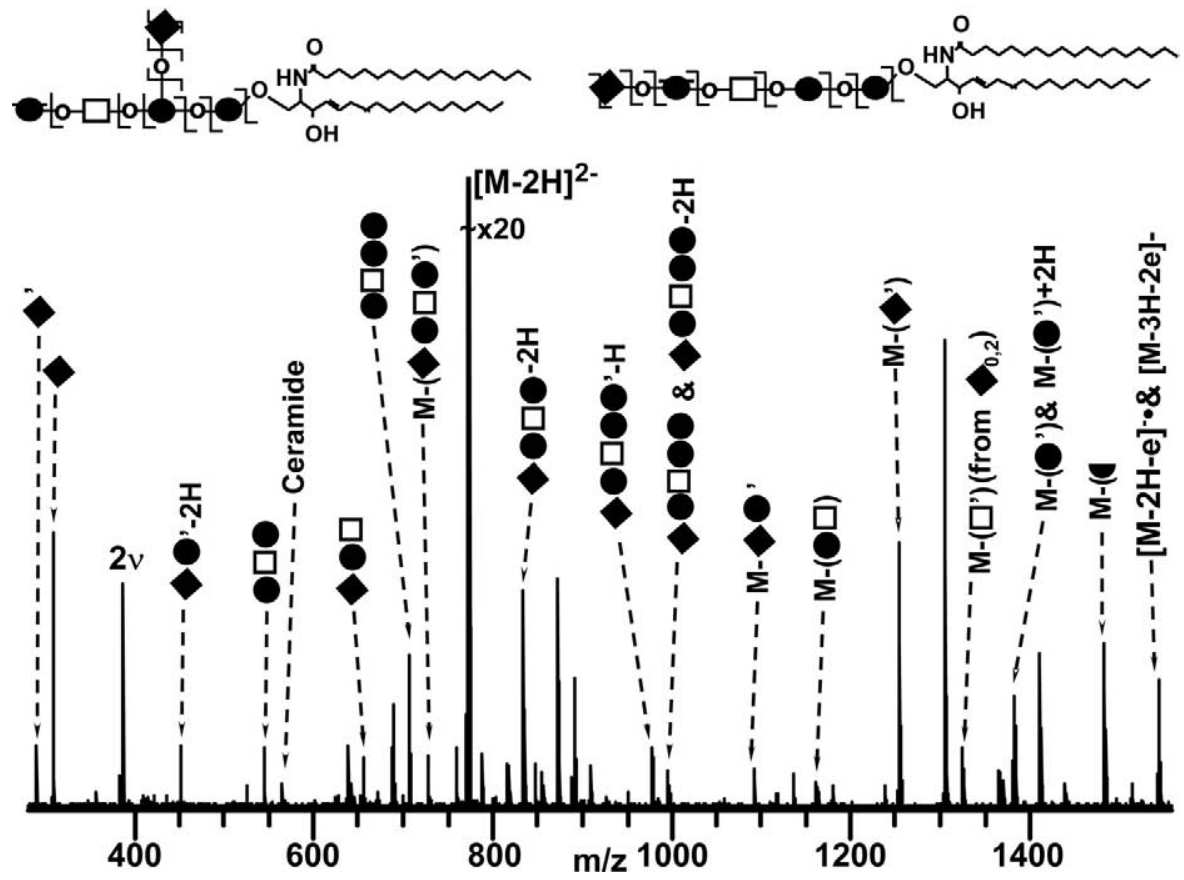

Figure 5. Product negative-ion mass spectrum following EDD (1 s irradiation) FT-ICR MS/MS of the quadrupole- and SWIFT-isolated doubly deprotonated GM1 precursor (100 scans). Most water loss fragments also show a loss of $\mathrm{H}$. (not labeled). Mass defect graphical analysis (not shown) also suggests multiple neutral losses or cross-ring cleavages not yet identified. EDD offers a negative-ion alternative to IRMPD but suffers from low efficiency of precursor to product ion conversion. The prevalent loss of $\mathrm{H}$ - combined with the $2 \mathrm{H}$ loss associated with the presence of sialic acid complicates EDD for structural analysis of gangliosides, at least until more is understood of this fragmentation technique. (Symbol with a through bar denote cross-ring cleavage).

\section{Electron Capture Dissociation (ECD) of Positive Ions}

The ECD mass spectrum offers further and more convincing diagnostic evidence for the GM1 structure (and the presence of a minor GM1b component). Figure 4 shows the product ion spectrum obtained from ECD (50 ms irradiation) of doubly protonated d18:1/C18:0 GM1 (50 scans). Fragmentation of glycopeptides by ECD is dominated by cleavage along the peptide backbone, with little to no cleavage of the glycan [30, 33]. In contrast, ECD of gangliosides produces extensive fragmentation throughout the glycan moiety, including cleavage at all glycosidic bonds except for the terminal hexose of GM1a. In fact, in one ECD spectrum we generate fragments which provide information on every region of the ganglioside. ECD produces the diagnostic trio of peaks corresponding to the ceramide portion of the precursor, as well as product ions identifying both the fatty acid and the sphingosine chains of the ceramide region. Assignment of the fragments corresponding to fragmentation within the ceramide, as well as loss of the fatty acid $+\mathrm{NH}_{2}$ from the parent (not labeled), are confirmed by mass defect (see Figure 7). Unique to ECD is the noticeable loss of the acetyl moiety, confirming the presence of an N-acetylated sugar [32]. Much more frequently, both ECD and EDD (see below) yield fragment ions associated with the loss of sialic acid as well as a second set of fragment ions corresponding to a loss of 2H (labeled by stars in Figure 5) [10, 12].

Similar to IRMPD, ECD confirms the presence of the GM1a isomer based on complementary fragment ions corresponding to the presence and loss of the disaccharide HexHexNAc' at $m / z 366.139$ and 1181.752 (Table 3). We also see confirmation of GM1b by the presence of the MHexNeuAc and its disaccharide complement, as in negative-ion IRMPD. However, ECD offers more conclusive evidence for the presence of GM1b. We see the same loss of the trisaccharide HexHexNAcNeuAc as for IRMPD, again suggesting the presence of GM1b. But with ECD we also see the all important complementary fragment ion corresponding to the trisaccharide at $m / z$ 675.245. In fact, we see complementary polysaccharide fragments for all sugar losses, offering much more conclusive evidence for the presence of two isomeric structures, the primary component GM1a and the much less abundant GM1b.

It is intriguing to note that the presence of so many complementary ion pairs may suggest that ECD can provide extensive coverage of the glycan region of gangliosides by primary fragmentation, retaining information on the connectivity of the sugars. Because ECD fragments are likely generated before the deposited energy is redistributed [25], ECD shows little to no preference for cleavage of labile bonds in peptides and proteins [51]. In addition, secondary capture of electrons by the singly 
Table 3. Molecular assignments and neutral masses of product ions of GM1 in ECD of the doubly protonated precursor ion

\begin{tabular}{|c|c|c|c|c|c|c|}
\hline$(z)$ & Measured $\mathrm{m} / \mathrm{z}$ & $\Delta$ Precursor & Assignment & Formula & $\begin{array}{c}\text { Calculated } \\
\qquad m / z\end{array}$ & error (ppm) \\
\hline (1) & 204.0863 & 1342.7977 & HexNAc' or A1 of NeuAc & $\mathrm{C}_{8} \mathrm{H}_{13} \mathrm{NO}_{5}$ & 204.0867 & +1.7 \\
\hline (1) & 264.2682 & 1282.6158 & sphingosine" & $\mathrm{C}_{18} \mathrm{H}_{33} \mathrm{~N}$ & 264.2686 & +1.3 \\
\hline (1) & 274.0917 & 1272.7923 & NeuAc" & $\mathrm{C}_{11} \mathrm{H}_{15} \mathrm{NO}_{7}$ & 274.0921 & +1.3 \\
\hline (1) & 284.2943 & 1262.5897 & fatty acid $+\mathrm{NH}_{2}{ }^{*}$ & $\mathrm{C}_{18} \mathrm{H}_{37} \mathrm{NO}$ & 284.2948 & +1.6 \\
\hline (1) & 292.1023 & 1254.7817 & NeuAc' & $\mathrm{C}_{11} \mathrm{H}_{17} \mathrm{NO}_{8}$ & 292.1027 & +1.2 \\
\hline (1) & 366.1389 & 1180.7451 & HexHexNAc' & $\mathrm{C}_{14} \mathrm{H}_{23} \mathrm{NO}_{10}$ & 366.1395 & +1.5 \\
\hline (1) & 454.1549 & 1092.7291 & HexNeuAc' & $\mathrm{C}_{17} \mathrm{H}_{27} \mathrm{NO}_{13}$ & 454.1555 & +1.2 \\
\hline (1) & 530.5286 & 1016.3554 & ceramide" \& -H & $\mathrm{C}_{36} \mathrm{H}_{67} \mathrm{NO}$ & 530.5295 & +1.6 \\
\hline (1) & 548.5392 & 998.3448 & ceramide' \& $-2 \mathrm{H}$ & $\mathrm{C}_{36} \mathrm{H}_{69} \mathrm{NO}_{2}$ & 548.5401 & +1.6 \\
\hline (1) & 566.5498 & 980.3342 & ceramide & $\mathrm{C}_{36} \mathrm{H}_{71} \mathrm{NO}_{3}$ & 566.5507 & +1.5 \\
\hline (1) & 675.2449 & 871.6391 & HexHexNAcNeuAc & $\mathrm{C}_{25} \mathrm{H}_{42} \mathrm{~N}_{2} \mathrm{O}_{19}$ & 675.2455 & +0.8 \\
\hline (1) & 710.5924 & 836.2916 & 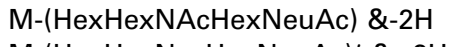 & $\mathrm{C}_{42} \mathrm{H}_{79} \mathrm{NO}_{7}$ & 710.5930 & +0.8 \\
\hline (1) & 728.6029 & 818.2811 & M-(HexHexNacHexNeuAc) $)^{\prime} \&-2 \mathrm{H}$ & $\mathrm{C}_{42} \mathrm{H}_{81} \mathrm{NO}_{8}$ & 728.6036 & +0.9 \\
\hline (2) & 773.9451 & 0.0011 & {$[\mathrm{M}+2 \mathrm{H}]^{2+}$} & $\mathrm{C}_{73} \mathrm{H}_{131} \mathrm{~N}_{3} \mathrm{O}_{31}$ & 773.9456 & +0.6 \\
\hline (1) & 819.2853 & 727.5987 & HexHexNAcHexNeuAc' \&-H & $\mathrm{C}_{31} \mathrm{H}_{50} \mathrm{~N}_{2} \mathrm{O}_{23}$ & 819.2877 & +2.9 \\
\hline (1) & 856.6499 & 690.2341 & $\mathrm{M}-(\mathrm{HexHexNAcNeuAc)-O} \&-2 \mathrm{H}$ & $\mathrm{C}_{48} \mathrm{H}_{89} \mathrm{NO}_{11}$ & 856.6509 & +1.1 \\
\hline (1) & 872.6448 & 674.2392 & M-(HexHexNAcNeuAc) \&-2H & $\mathrm{C}_{48} \mathrm{H}_{89} \mathrm{NO}_{12}$ & 872.6458 & +1.1 \\
\hline (1) & 890.6561 & 656.2279 & M-(HexHexNAcNeuAc)' \&-2H & $\mathrm{C}_{48} \mathrm{H}_{91} \mathrm{NO}_{13}$ & 890.6564 & +0.3 \\
\hline (1) & 981.3394 & 565.5446 & glycan' \&-H & $\mathrm{C}_{37} \mathrm{H}_{60} \mathrm{~N}_{2} \mathrm{O}_{28}$ & 981.3405 & +1.1 \\
\hline (1) & 999.3502 & 547.5338 & glycan & $\mathrm{C}_{37} \mathrm{H}_{62} \mathrm{~N}_{2} \mathrm{O}_{29}$ & 999.3511 & +0.9 \\
\hline (1) & 1075.7258 & 471.1582 & M-(HexNeuAc) & $\mathrm{C}_{56} \mathrm{H}_{102} \mathrm{~N}_{2} \mathrm{O}_{17}$ & 1075.7252 & -0.6 \\
\hline (1) & 1163.7414 & 383.1426 & M-(HexHexNAc) & $\mathrm{C}_{59} \mathrm{H}_{106} \mathrm{~N}_{2} \mathrm{O}_{20}$ & 1163.7412 & -0.2 \\
\hline (1) & 1181.7522 & 365.1318 & M-(HexHexNAc)' & $\mathrm{C}_{59} \mathrm{H}_{108} \mathrm{~N}_{2} \mathrm{O}_{21}$ & 1181.7518 & -0.4 \\
\hline (1) & 1235.7618 & 311.1222 & $\mathrm{M}-(\mathrm{NeuAc})-2 \mathrm{H}$ & $\mathrm{C}_{62} \mathrm{H}_{110} \mathrm{~N}_{2} \mathrm{O}_{22}$ & 1235.7623 & +0.4 \\
\hline (1) & 1237.7751 & 309.1089 & M-NeuAc & $\mathrm{C}_{62} \mathrm{H}_{112} \mathrm{~N}_{2} \mathrm{O}_{22}$ & 1237.7780 & +2.3 \\
\hline (1) & 1253.7729 & 293.1111 & $\mathrm{M}-(\mathrm{NeuAc})^{\prime}-2 \mathrm{H}$ & $\mathrm{C}_{62} \mathrm{H}_{112} \mathrm{~N}_{2} \mathrm{O}_{23}$ & 1253.7729 & -0.04 \\
\hline (1) & 1255.7831 & 291.1009 & M-NeuAc' & $\mathrm{C}_{62} \mathrm{H}_{114} \mathrm{~N}_{2} \mathrm{O}_{23}$ & 1255.7886 & +4.3 \\
\hline (1) & 1262.6091 & 284.2749 & $\mathrm{M}-\left(\right.$ fatty acid $\left.+\mathrm{NH}_{2}\right)$ & $\mathrm{C}_{55} \mathrm{H}_{95} \mathrm{~N}_{3} \mathrm{O}_{29}$ & 1262.6124 & +2.6 \\
\hline (1) & 1325.7949 & 221.0891 & M-HexNAc or M-A1 of NeuAc & $\mathrm{C}_{65} \mathrm{H}_{116} \mathrm{~N}_{2} \mathrm{O}_{25}$ & 1325.7941 & -0.6 \\
\hline (1) & 1504.8743 & 42.0097 & $\mathrm{M}-\mathrm{C}_{2} \mathrm{H}_{2} \mathrm{O}$ (-acetyl) & $\mathrm{C}_{71} \mathrm{H}_{129} \mathrm{~N}_{3} \mathrm{O}_{30}$ & 1504.8734 & -0.6 \\
\hline (1) & 1528.8734 & 18.0106 & {$[\mathrm{M}+\mathrm{H}]^{+}-\mathrm{H}_{2} \mathrm{O}$} & $\mathrm{C}_{73} \mathrm{H}_{129} \mathrm{~N}_{3} \mathrm{O}_{30}$ & 1528.8734 & -0.03 \\
\hline (1) & 1546.8853 & -0.0013 & {$[\mathrm{M}+\mathrm{H}]^{+}$} & $\mathrm{C}_{73} \mathrm{H}_{131} \mathrm{~N}_{3} \mathrm{O}_{31}$ & 1546.8840 & -0.9 \\
\hline (1) & 1547.8869 & 0.0044 & {$[\mathrm{M}+2 \mathrm{H}+\mathrm{e}]^{+\bullet}$} & $\mathrm{C}_{73} \mathrm{H}_{131} \mathrm{~N}_{3} \mathrm{O}_{31}$ & 1547.8917 & +3.1 \\
\hline
\end{tabular}

charged product ions of GM1 would result in neutralization, so that any subsequent fragmentation will not be observable by mass spectrometry. However, multiple peptide backbone cleavages in cyclic peptides [52] and secondary side chain cleavages in linear peptides [53] have both been shown to be induced by capture of a single electron. Further investigation and a wider range of pure gangliosides will be required to establish whether capture of an electron results in single or multiple cleavages within the glycan.

\section{Electron Detachment Dissociation (EDD) of Negative Ions}

Figure 5 (see also Table 4) shows the negative product ion mass spectrum obtained by EDD (1 s electron irradiation) FT-ICR MS/MS of the quadrupole- and SWIFT-isolated doubly deprotonated d18:1/C18:0 GM1 precursor (100 scans). Little is known of the actual mechanism for EDD fragmentation, although it is postulated to involve electron-hole recombination [27]. Moreover, the lack of charge mediation in negative-ion fragmentation makes interpretation of the spectra difficult. As for negative-ion IRMPD, cleavage is seen between all sugars. However, no cleavage is seen within the ceramide. In addition, most water loss fragments also show a loss of $\mathrm{H}$. (not shown). Frequent loss of $\mathrm{H} \cdot$ combined with the $2 \mathrm{H}$ loss associated with the loss of sialic acid makes assignment of novel fragmentation difficult. Several relatively abundant fragment ions remain unassigned. EDD does offer a negative-ion alternative to IRMPD but its low efficiency of precursor to product ion conversion combined with the ambiguity in novel assignments makes this technique difficult for structural analysis of gangliosides, at least until more is understood of this fragmentation technique. EDD of nonsialylated glycosphingolipids, which would eliminate the confusion of a loss of two hydrogens could prove more useful in deciphering novel fragmentation patterns such as possible cross-ring cleavages.

\section{Mass Defect Analysis}

Many species in the mass spectra of Figures 2-5 may be assigned by matching the accurately measured (to $\sim 1$ ppm) mass to a putative elemental composition, $\mathrm{C}_{\mathrm{c}} \mathrm{H}_{\mathrm{h}} \mathrm{N}$ ${ }_{n} \mathrm{O}_{\mathrm{o}}$, corresponding to conventional bond cleavages (e.g., peptidic, glycosidic). Assignment of species corresponding to other cleavages, e.g., cross-ring, with the simultaneous complication of losses of $\mathrm{H} \cdot, 2 \mathrm{H}, \mathrm{H}_{2} \mathrm{O}$, etc. is much more difficult. However, it is possible to distinguish lipid 
Table 4. Molecular assignments and neutral masses of product ions of GM1 in EDD of the doubly deprotonated precursor ion

\begin{tabular}{|c|c|c|c|c|c|c|}
\hline (z) & measured $\mathrm{m} / \mathrm{z}$ & $\Delta$ precursor & assignment & formula & $\begin{array}{c}\text { calc'd } \\
m / z\end{array}$ & error (ppm) \\
\hline (1) & 290.0876 & 1254.7819 & $\mathrm{NeuAc}-\mathrm{H}_{2} \mathrm{O}$ & $\mathrm{C}_{11} \mathrm{H}_{17} \mathrm{NO}_{8}$ & 290.0882 & +1.9 \\
\hline (1) & 308.0982 & 1236.7713 & NeuAc and NeuAc- $\mathrm{H}^{\bullet}$ & $\mathrm{C}_{11} \mathrm{H}_{19} \mathrm{NO}_{9}$ & 308.0988 & +1.8 \\
\hline (1) & 450.1246 & 1094.7449 & HexNeuAc'-2H & $\mathrm{C}_{17} \mathrm{H}_{25} \mathrm{NO}_{13}$ & 450.1253 & +1.6 \\
\hline (1) & 564.5353 & 980.3342 & ceramide & $\mathrm{C}_{36} \mathrm{H}_{71} \mathrm{NO}_{3}$ & 564.5362 & +1.5 \\
\hline (1) & 655.2196 & 889.6499 & HexHexNAcNeuAc$c^{\prime} \&-H^{\bullet}$ & $\mathrm{C}_{25} \mathrm{H}_{40} \mathrm{~N}_{2} \mathrm{O}_{18}$ & 655.2204 & +1.1 \\
\hline (1) & 706.2404 & 838.6291 & HexHexNAcHexHex & $\mathrm{C}_{26} \mathrm{H}_{45} \mathrm{NO}_{21}$ & 706.2412 & +1.1 \\
\hline (1) & 726.5886 & 818.2809 & M-(HexHexNAcHexNeuAc)' & $\mathrm{C}_{42} \mathrm{H}_{81} \mathrm{NO}_{8}$ & 726.5891 & +0.6 \\
\hline (2) & 771.9300 & 0.0022 & {$[\mathrm{M}-2 \mathrm{H}]^{2-}$} & $\mathrm{C}_{73} \mathrm{H}_{13} 1 \mathrm{~N}_{3} \mathrm{O}_{31}$ & 771.9311 & +1.4 \\
\hline (1) & 833.2679 & 711.6016 & HexHexNAcNeuAc-2H & $\mathrm{C}_{31} \mathrm{H}_{50} \mathrm{~N}_{2} \mathrm{O}_{24}$ & 833.2682 & +0.3 \\
\hline (1) & 978.3177 & 566.5518 & glycan'- $\mathrm{H}^{\bullet}$ & $\mathrm{C}_{37} \mathrm{H}_{59} \mathrm{~N}_{2} \mathrm{O}_{28}$ & 978.3182 & +0.5 \\
\hline (1) & 995.3209 & 549.5486 & glycan-2H & $\mathrm{C}_{37} \mathrm{H}_{60} \mathrm{~N}_{2} \mathrm{O}_{29}$ & 995.3210 & +0.1 \\
\hline (1) & 997.3359 & 547.5336 & glycan & $\mathrm{C}_{37} \mathrm{H}_{62} \mathrm{~N}_{2} \mathrm{O}_{29}$ & 997.3366 & +0.7 \\
\hline (1) & 1091.7222 & 453.1473 & M-(HexNeuAc)' & $\mathrm{C}_{56} \mathrm{H}_{104} \mathrm{~N}_{2} \mathrm{O}_{18}$ & 1091.7212 & -1.0 \\
\hline (1) & 1161.7244 & 383.1451 & M-(HexHexNAc) & $\mathrm{C}_{59} \mathrm{H}_{106} \mathrm{~N}_{2} \mathrm{O}_{20}$ & 1161.7267 & +2.0 \\
\hline (1) & 1253.7738 & 291.0957 & $\mathrm{M}-(\mathrm{NeuAc})^{\prime} \quad \&-\mathrm{H}^{\bullet}$ & $\mathrm{C}_{62} \mathrm{H}_{114} \mathrm{~N}_{2} \mathrm{O}_{23}$ & 1253.7740 & +0.1 \\
\hline (1) & 1324.7871 & 220.0824 & $\mathrm{M}-(\mathrm{HexNAc})+\mathrm{H}$ & $\mathrm{C}_{65} \mathrm{H}_{117} \mathrm{~N}_{2} \mathrm{O}_{25}$ & 1324.7873 & +0.1 \\
\hline (1) & 1382.8138 & 162.0557 & $\mathrm{M}-\left(\mathrm{Hex}-\mathrm{H}_{2} \mathrm{O}\right)$ & $\mathrm{C}_{67} \mathrm{H}_{121} \mathrm{~N}_{3} \mathrm{O}_{26}$ & 1382.8166 & +2.0 \\
\hline (1) & 1380.7992 & 164.0703 & $\mathrm{M}-($ Hex-O) & $\mathrm{C}_{67} \mathrm{H}_{119} \mathrm{~N}_{3} \mathrm{O}_{26}$ & 1380.8010 & +1.3 \\
\hline (1) & 1482.8345 & 62.0350 & $\mathrm{M}-\mathrm{HexA} 2$ & $\mathrm{C}_{71} \mathrm{H}_{125} \mathrm{~N}_{3} \mathrm{O}_{29}$ & 1482.8327 & -1.2 \\
\hline (1) & 1542.8534 & 1.0088 & {$[\mathrm{M}-3 \mathrm{H}-2 \mathrm{e}]^{-}$} & $\mathrm{C}_{73} \mathrm{H}_{130} \mathrm{~N}_{3} \mathrm{O}_{31}$ & 1542.8538 & +0.3 \\
\hline (1) & 1543.8606 & 0.0016 & {$[\mathrm{M}-2 \mathrm{H}-\mathrm{e}]^{-\bullet}$} & $\mathrm{C}_{73} \mathrm{H}_{131} \mathrm{~N}_{3} \mathrm{O}_{31}$ & 1543.8617 & +0.7 \\
\hline
\end{tabular}

from oligosaccharide from liposaccharide, and even determine the number of fatty acid chains and/or number of sugars, based simply on differences in fractional mass (i.e., the decimal portion of the exact mass). Mass defect graphical analysis [54-56] is particularly successful for structural analysis of glycolipids because of the significant compositional differences between sugars versus lipids

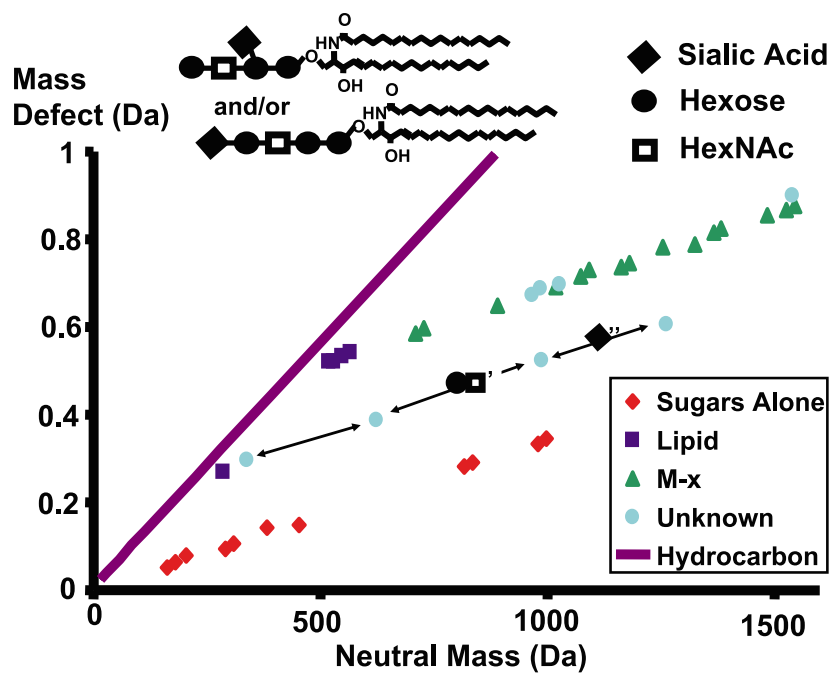

Figure 6. Mass defect graphical analysis of the IRMPD of doubly deprotonated GM1 spectra shown in Figure 3. The high mass resolving power of FT-ICR MS/MS allows localization of product ion masses to specific regions of the ganglioside based solely on mass defect graphical analysis. Product ion masses separate themselves into distinct lines, with those containing lipid eventually intercepting the theoretical hydrocarbon line. This graph shows the existence of a significant loss of hydrocarbon chain (most likely fatty acid) followed by a series of sugar losses from the remaining long-chain base, a series of secondary fragmentation that would not have been easy to pick out by product ion masses alone. greatly simplifies assignment of MS-MS data. Figure 6 and Figure 7 illustrate the ease with which product ion masses can be assigned to specific regions of the ganglioside. Product ion masses separate themselves into distinct lines, with those containing lipid eventually intercepting the theoretical hydrocarbon line. Graphical analysis of product ion data for the negative-ion IRMPD of GM1 (Figure 6) makes evident the existence of a significant loss of hydrocarbon chain (most likely loss of fatty acid) followed by a series of secondary sugar losses from the remaining longchain base, a series that would not have been easy to pick out from product ion masses alone. Trends in fragmenta-

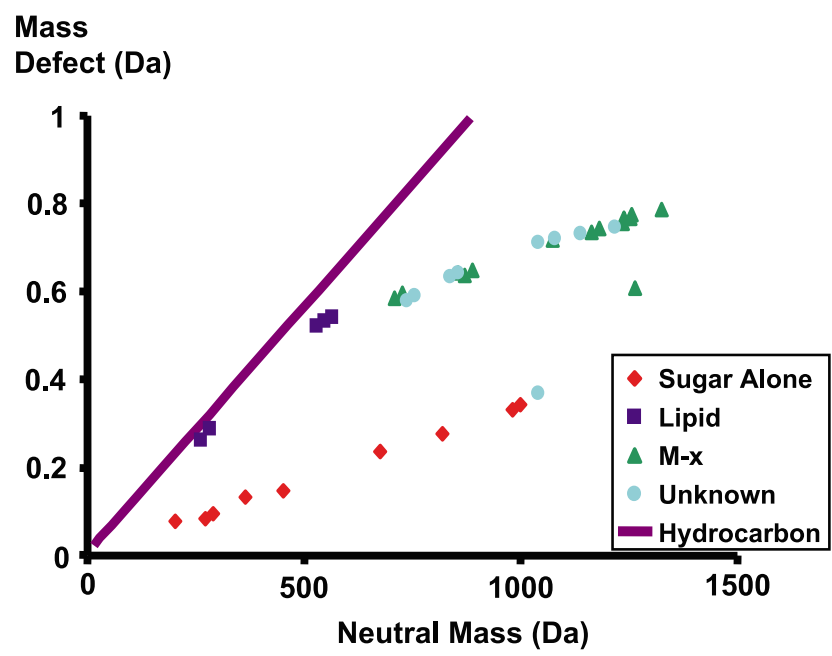

Figure 7. Mass defect graphical analysis of the ECD spectra shown in Figure 4. Assignment of the fragments corresponding to cleavage on either side of the nitrogen of the ceramide is confirmed, as well as identification of the presence of a complimentary $\mathrm{M}-$ (loss of the fatty acid + NH2) (not labeled in Figure 4). 
tion patterns, such as the significant secondary fragmentation of IRMPD, are easily visualized and provide additional insight into the pattern of fragmentation. Similarly, mass defect graphical analysis for ECD of GM1 (Figure 7) supports the possibility that there may be little to no secondary fragmentation within the glycan following initial electron capture. Here we see a similar loss of a hydrocarbon chain as well as its compliment but no intermediate sequence of sugar loss, suggestion primary fragmentation as the origin of sugar fragments. Graphical analysis of EDD fragment ion data (not shown) shows only a series of sugar loss from the parent and a series of sugars. All unassigned peaks fall into one of these two lines, suggesting cross-ring cleavage or extensive neutral loss for the yet unassigned fragments.

\section{Conclusions}

The FT-ICR MS/MS techniques of infrared multiphoton dissociation, electron capture dissociation, and electron detachment dissociation produce extensive fragmentation of the protonated and deprotonated GM1 ganglioside. ECD offers the most promise because its extensive fragmentation, as well as the possibility of little to no secondary fragmentation, allows for a more definitive determination of glycan sequence. In addition, ECD identifies both halves of the ceramide and cleaves the acetyl moiety to identify the presence of acetylated sugars. IRMPD of both positive and negative ions produces extensive fragmentation, but requires multiple experiments at different laser power, and also leads to secondary fragmentation, whereas a single ECD experiment provides comparable or more information. However, stepwise fragmentation by IRMPD is useful to map the relative lability among a series of cleavages. Cleavage between the two halves of the ceramide is seen by negative-ion (but not positive-ion) IRMPD, although we do observe such cleavage by positive-ion IRMPD of sulfatides. EDD provides extensive fragmentation of negative ions, but suffers from low efficiency as well as complication of data analysis by frequent hydrogen atom loss. Finally, mass defect analysis can help to distinguish lipid from glycan from glycolipid as an aid in assignment of MS/MS data.

\section{Acknowledgments}

The authors thank Michael J. Chalmers, Matthew B. Renfrow, and Mark R. Emmett for helpful discussions. The authors gratefully acknowledge the financial support of the National Science Foundation (CHE 99-09502), Vetenskapsrådet (14113; A0692; K200403X-09909-11C), the National High Magnetic Field Laboratory in Tallahassee, FL, Florida State University, the Royal Society of Arts and Sciences in Göteborg, and the Swedish Foundation for International Cooperation in Research and Higher Education (STINT).

\section{References}

1. Svennerholm, L. Designation and Schematic Structure of Gangliosides and Allied Glycosphingolipids. In Biological Function of Gangliosides; Vol. CI; Elsevier Science: Amsterdam, 1994; pp R11-R14.

2. Karlsson, K. A. Animal Glycosphingolipids as Membrane Attachment Sites for Bacteria. Annu. Rev. Biochem. 1989, 58, 309-350.

3. Hakomori, S. Traveling for the Glycosphingolipid Path. Glycoconj. J. 2000, 17, 627-647.

4. Futerman, A. H.; Hannun, Y. A. The Complex Life of Simple Sphingolipids. EMBO. J. 2004, 8, 777-782.

5. Svennerholm, L.; Fredman, P. A Procedure for the Quantitative Isolation of Brain Gangliosides. Biochim. Biophys. Acta. 1980, 617, 97-109.

6. Mansson, J. E.; Holmgren, J.; Li, Y. T.; Vanier, M. T.; Svennerholm, L. Chemical and Immunological Characterization of the Major Glucosamine-Containing Gangliosides of Human Tissues. Med. Biol. 1974, 52, 240-243.

7. Kannagi, R.; Nudelman, E.; Hakomori, S. I. Possible Role of Ceramide in Defining Structure and Function of Membrane Glycolipids. Proc. Nat. Acad. Sci. U.S.A. 1982, 79, 3470-3474.

8. Mansson, J. E.; Svennerholm, L.The Use of Galactosylceramides with Uniform Fatty Acids as Substrates in the Diagnosis and Carrier Detection of Krabbe Disease. Clin. Chim. Acta 1982, $126,127-133$.

9. Lingwood, C. A. Aglycone Modulation of Glycolipid Receptor Function. Glycoconj. J. 1996, 13, 495-503.

10. Egge, H.; Peterkatalinic, J.; Reuter, G.; Schauer, R.; Ghidoni, R.; Sonnino, S.; Tettamanti, G. Analysis of Gangliosides Using Fast Atom Bombardment Mass-Spectrometry. Chem. Phys. Lipids 1985, 37, 127-141.

11. Ladisch, S.; Sweeley, C. C.; Becker, H.; Gage, D. Aberrant Fatty Acyl $\alpha$-Hydroxylation in Human Neuro-Blastoma Tumor Gangliosides. J. Biol. Chem. 1989, 264, 12097-12105.

12. Domon, B.; Costello, C. E. Structure Elucidation of Glycosphingolipids and Gangliosides Using High-Performance Tandem Mass-Spectrometry. Biochemistry 1988, 27, 1534-1543.

13. Juhasz, P.; Costello, C. E. Matrix-Assisted Laser Desorption Ionization Time-of-Flight Mass-Spectrometry of Underivatized and Permethylated Gangliosides. J. Am. Soc. Mass Spectrom. 1992, 3, 785-796.

14. Yohe, H. C.; Wallace, P. K.; Berenson, C. S.; Ye, S.; Reinhold, B. B.; Reinhold, V. N. The Major Gangliosides of Human Peripheral Blood Monocytes/Macrophages: Absence of Ganglio Series Structures. Glycobiology 2001, 11, 831-841.

15. Metelmann, W.; Peter-Katalinic, J.; Muthing, J. Gangliosides from Human Granulocytes: A Nano-ESI QTOF Mass Spectrometry Fucosylation Study of Low Abundance Species in Complex Mixtures. J. Am. Soc. Mass Spectrom. 2001, 12, 964-973.

16. Metelmann, W.; Vukelic, Z.; Peter-Katalinic, J. Nano-Electrospray Ionization Time-of-flight Mass Spectrometry of Gangliosides from Human Brain Tissue. J. Mass Spectrom. 2001, 36, 21-29.

17. Isaac, G.; Bylund, D.; Mansson, J. E.; Markides, K. E.; Bergquist, J. Analysis of Phosphatidylcholine and Sphingomyelin Molecular Species from Brain Extracts using Capillary Liquid Chromatography Electrospray Ionization Mass Spectrometry. J. Neurosci. Methods 2003, 128, 111-119.

18. Marshall, A. G.; Hendrickson, C. L.; Jackson, G. S. Fourier Transform Ion Cyclotron Resonance Mass Spectrometry: A Primer. Mass Spectrom. Rev. 1998, 17, 1-35.

19. Marshall, A. G. Milestones in Fourier Transform Ion Cyclotron Resonance Mass Spectrometry Technique Development. Int. J. Mass Spectrom 2000, 200, 331-356.

20. Gauthier, J. W.; Trautman, T. R.; Jacobson, D. B. Sustained Off-Resonance Irradiation for CAD Involving FTMS. CAD Technique that Emulates Infrared Multiphoton Dissociation. Anal. Chim. Acta. 1991, 246, 211-225.

21. McLuckey, S. A. Principles of Collisional Activation in Analytical Mass-Spectrometry. J. Am. Soc. Mass Spectrom. 1992, 3, 599-614. 
22. Senko, M. W.; Speir, J. P.; McLafferty, F. W. Collisional Activition of Large Multiply-Charged Ions Using Fourier Transform Mass Spectrometry. Anal. Chem. 1994, 66, 2801-2808.

23. Woodlin, R. L.; Bomse, D. S.; Beauchamp, J. L. Multiphoton Dissociation of Molecules with Low Power Continuous Wave Infrared Laser Radiation. J. Am. Chem. Soc. 1978, 100, 3248-3250.

24. Little, D. P.; Speir, J. P.; Senko, M. W.; O'Connor, P. B.; McLafferty, F. W. Infrared Multiphoton Dissociation of Large Multiply-Charged Ions For Biomolecule Sequencing. Anal. Chem. 1994, 66, 2809-2815.

25. Zubarev, R. A.; Kelleher, N. L.; McLafferty, F. W. Electron Capture Dissociation of Multiply Charged Protein Cations. A Nonergodic Process. J. Am. Chem. Soc. 1998, 120, 3265-3266.

26. Zubarev, R. A.; Horn, D. M.; Fridriksson, E. K.; Kelleher, N. L.; Kruger, N. A.; Lewis, M. A.; Carpenter, B. K.; McLafferty, F. W. Electron Capture Dissociation for Structural Characterization of Multiply Charged Protein Cations. Anal. Chem. 2000, 72, 563-573.

27. Budnik, B. A.; Haselmann, K. F.; Zubarev, R. A. Electron Detachment Dissociation of Peptide Di-Anions: An Electron-Hole Recombination Phenomenon. Chem. Phys. Lett. 2001, 342, 299-302.

28. Gaucher, S. P.; Cancilla, M. T.; Phillips, N. J.; Gibson, B. W.; Leary, J. A. Mass Spectral Characterization of Lipooligosaccharides from Haemophilus influenzae 2019. Biochemistry 2000, 39, 12406-12414.

29. Mirgorodskaya, E.; O'Connor, P. B.; Costello, C. E. A General Method for Precalculation of Parameters for Sustained OffResonance Irradiation/Collision-Induced Dissociation. J. Am. Soc. Mass Spectrom. 200213, 318-324.

30. Mirgorodskaya, E.; Roepstorff, P.; Zubarev, R. A. Localization of O-Glycosylation Sites in Peptides by Electron Capture Dissociation in a Fourier Transform Mass Spectrometer. Anal. Chem. 1999, 71, 4431-4436.

31. Guan, Z. Identification and Localization of the Fatty Acid Modification in Ghrelin by Electron Capture Dissociation. J. Am. Soc. Mass Spectrom. 2002, 13, 1443-1447.

32. Budnik, B. A.; Haselmann, K. F.; Elkin, Y. N.; Gorbach, V. I.; Zubarev, R. A. Applications of Electron-Ion Dissociation Reactions for Analysis of Polycationic Chitooligosaccharides in Fourier Transform Mass Spectrometry. Anal. Chem. 2003, 75, 5994-6001.

33. Håkansson, K.; Cooper, H. J.; Emmett, M. R.; Costello, C. E.; Marshall, A. G.; Nilsson, C. L. Electron Capture Dissociation and Infrared Multiphoton Dissociation MS/MS of an NGlycosylated Tryptic Peptide Yield Complementary Sequence Information. Anal. Chem. 2001, 73, 4530-4536.

34. Mansson, J. E.; Fredman, P.; Bigner, D. D.; Molin, K.; Rosengren, B.; Friedman, H. S.; Svennerholm, L. Characterization of New Gangliosides of the Lactotetraose Series in Murine Xenografts of a Human Glioma Cell Line. FEBS Lett. 1986, 201, 109-113.

35. Mansson, J. E.; Mo, H.; Egge, H.; Svennerholm, L. Trisialosyllactosylceramide (GT3) is a Ganglioside of Human Lung. FEBS Lett. 1986, 196, 259-262.

36. Svennerholm, L.; Rynmark, B. M.; Vilbergson, G.; Fredman, P.; Gottfries, J.; Mansson, J. E.; Percy, A. Gangliosides in Human Brain. J. Neurochem. 1991, 56, 1763-1768.

37. Senko, M. W.; Hendrickson, C. L.; PasaTolic, L.; Marto, J. A.; White, F. M.; Guan, S. H.; Marshall, A. G. Electrospray Ionization Fourier Transform Ion Cyclotron Resonance at 9.4 T. Rapid Commun. Mass Spectrom. 1996, 10, 1824-1828.

38. Blakney, G.; Lam, T.; Hendrickson, C. L.; Marshall, A. G. FT-ICR MS Data Station for Automated High Speed DataDependent Acquisition. Proceedings of the 52nd ASMS Conference on Mass Spectrometry and Allied Topics; Nashville, TN, 2004.

39. Quinn, J. P.; Emmett, M. R.; Marshall, A. G. A Device for Fabrication of Emitters for Low-Flow Electrospray Ionization;
Proceedings of the 46th ASMS Conference on Mass Spectrometry and Allied Topics, Orlando FL, May 1998; pp 1388-1388

40. Hendrickson, C. L.; Quinn, J. P.; Emmett, M. R.; Marshall, A. G. Quadrupole Mass Filtered External Accumulation for Fourier Transform Ion Cyclotron Resonance Mass Spectrometry. Proceedings of the 48th ASMS Conference on Mass Spectrometry and Allied Topics; Long Beach, CA, June 2000.

41. Hendrickson, C. L.; Quinn, J. P.; Emmett, M. R.; Marshall, A. G. Mass-Selective External Ion Accumulation for Fourier Transform Ion Cyclotron Resonance Mass Spectrometry. Proceedings of the 49th ASMS Conference on Mass Spectrometry and Allied Topics; Chicago, IL, May 2001.

42. Marshall, A. G.; Wang, T.-C. L.; Ricca, T. L. Tailored Excitation for Fourier Transform Ion Cyclotron Resonance Mass Spectrometry. J. Am. Chem. Soc. 1985, 107, 7893-7897.

43. Guan, S.; Marshall, A. G. Stored Waveform Inverse Fourier Transform (SWIFT) Ion Excitation in Trapped-Ion Mass Spectrometry: Theory and Applications. Int. J. Mass Spectrom. Ion Proc. 1996, 157/158, 5-37.

44. Wilcox, B. E.; Hendrickson, C. L.; Marshall, A. G. Improved Ion Extraction from a Linear Octopole Ion Trap: SIMION Analyis and Experimental Demonstration. J. Am. Soc. Mass Spectrom. 2002, 13, 1304-1312.

45. Beu, S. C.; Laude, D. A., Jr. Open Trapped Ion Cell Geometries for FT/ICR/MS. Int. J. Mass Spectrom. Ion Processes 1992, 112, 215-230.45.

46. Håkansson, K.; Chalmers, M. J.; Quinn, J. P.; McFarland, M. A.; Hendrickson, C. L.; Marshall, A. G. Combined Electron Capture and Infrared Multiphoton Dissociation for Multistage MS/MS in a Fourier Transform Ion Cyclotron Resonance Mass Spectrometer. Anal. Chem. 2003, 75, 3256-3262.

47. Ledford, E. B., Jr.; Rempel, D. L.; Gross, M. L. Space Charge Effects in Fourier Transform Mass Spectrometry Mass Calibration. Anal. Chem. 1984, 56, 2744-2748.

48. Shi, S. D.-H.; Drader, J. J.; Freitas, M. A.; Hendrickson, C. L.; Marshall, A. G. Comparison and Interconversion of the Two Most Common Frequency-to-Mass Calibration Functions for Fourier Transform Ion Cyclotron Resonance Mass Spectrometry. Int. J. Mass Spectrom. 2000, 195/196, 591-598.

49. Mansson, J. E.; Vanier, M. T.; Svennerholm, L. Changes in the Fatty Acid and Sphingosine Composition of the Major Gangliosides of Human Brain with Age. J. Neurochem. 1978, 30, 273-275.

50. McLuckey, S. A.; Goeringer, D. E. Slow Heating Methods in Tandem Mass Spectrometry. J. Mass Spectrom. 1997, 35, 461-474.

51. Kelleher, N. L.; Zubarev, R. A.; Bush, K.; Furie, B.; Furie, B. C.; McLafferty, F. W.; Walsh, C. T. Localization of Labile Posttranslational Modifications by Electron Capture Dissociation: The Case of $\gamma$-carboxyglutamic Acid. Anal. Chem. 1999, 71, $4250-4253$

52. Leymarie, N.; Costello, C. E.; O'Connor, P. B. Electron Capture Dissociation Initiates a Free Radical Reaction Cascade. J. Am. Chem. Soc. 2003, 125, 8949-8958.

53. Cooper, H. J.; Hudgins, R. R.; Håkansson, K.; Marshall, A. G. Secondary Fragmentation of Linear Peptides in Electron Capture Dissociation. Int. J. Mass Spectrom. 2003, 228, 723-728.

54. Hughey, C. A.; Hendrickson, C. L.; Rodgers, R. P.; Marshall, A. G.; Qian, K. Kendrick Mass Defect Spectrum: A Compact Visual Analysis for Ultrahigh-Resolution Broadband Mass Spectra. Anal. Chem. 2001, 73, 4676-81.

55. Pomerantz, S.; McCloskey, J. Fractional Mass Values of Large Molecules. J. Mass Spectrom. 1987, 22, 251-253.

56. Jones, J. J.; Stump, M. J.; Fleming, R. C.; Lay, J. O., Jr.; Wilkins, C. L. Strategies and Data Analysis Techniques for Lipid and Phospholipid Chemistry Elucidation by Intact Cell MALDIFTMS. J. Am. Soc. Mass Spectrom. 2004, 15, 1665-1674. 